\title{
WHOLE BUILDING ENERGY SIMULATION AND ENERGY SAVING POTENTIAL ANALYSIS OF A LARGE PUBLIC BUILDING
}

\author{
Yiqun $\mathrm{Pan}^{1}$, Mingming $\mathrm{Zuo}^{2}$, Gang $\mathrm{Wu}^{3}$ \\ ${ }^{1}$ Institute of Building Performance \& Technology, Sino-German College of Applied Sciences, \\ Tongji University, Shanghai, China \\ ${ }^{2}$ School of Mechanical Engineering, Tongji University, Shanghai, China \\ ${ }^{3}$ Weldtech Technology (Shanghai) Co. Ltd., China
}

\begin{abstract}
By comparing EnergyPlus with other energy simulation tools, this paper explores how to use EnergyPlus to construct models to accurately simulate complex building systems as well as the interrelationships among sub-systems such as HVAC, lighting and service hot water systems. Then energy consumption and cost of a large public building is simulated and calculated for LEED certification using EnergyPlus. ASHRAE baseline model is constructed according to ASHRAE 90.1 standard and the comparison of annual energy consumption between ASHRAE baseline model and proposed model is carried out. Moreover, an energy efficiency model is built based on the design model. In this model, shading performance of the transparent envelopes and operating performance of the building system components are improved. Meanwhile, other ECMs (energy saving measures) such as daylighting dimming and occupant sensors are considered. The simulation results show $4.7 \%$ electricity consumption decrease but $6.9 \%$ gas consumption increase of the energy efficiency model compared to ASHRAE baseline model. In summary, the annual energy cost of the energy efficiency model is reduced by $7.75 \%$.
\end{abstract}

\section{INTRODUCTION}

In a public building, there exist many spaces with quite different functions and structures which will certainly lead to more complicated building systems such as HVAC system, electric lighting system as well as service hot water system. Especially when more and more advanced building technologies become an important part of the composition of a large public building, it does show great difficulty in analyzing and evaluating the whole building energy consumption. EnergyPlus, which is a new generation building energy analysis tool, bears many advantages when compared to its ancestors and is suited to analyze building performances with non-normal building systems especially for large office buildings. Griffith et al employed EnergyPlus to study the influence of some advanced building technologies over the building performance of a public building in Teterboro airport and DOE-2.1 to analyze the effect of such common measures as optimized envelope system and schedules (Griffith et al. 2003). Ellis and Torcellini carried out research on the reliability of EnergyPlus in simulating tall buildings and the outcomes from their research proved accuracy and reliability of EnergyPlus in simulating tall buildings (Ellis and Torcellini 2005). Pan et al. analyzed a campus building equipped with a BCHP system based on the fully understanding of corresponding features of EnergyPlus and also studied its whole building energy and operation performance (Hartkopf et al. 2003 and Pan et al. 2005).

This paper first compares EnergyPlus to DOE-2.1 and TRNSYS over their capabilities in modeling buildings and their systems to find out the advantages of EnergyPlus as a whole building energy analysis tool. Then a large public building located in Shanghai is simulated with EnergyPlus as an example to explore how to properly simulate building subsystems and their corresponding control strategies. The simulation results of this building are analyzed.

\section{COMPARISON OF ENERGY SIMULATION TOOLS}

EnergyPlus is an hourly energy simulation engine which employs a simultaneous load/system/plant simulation methodology. In load calculation, CTF method is used to calculate heat conduction through envelopes and then a heat balance method for zone load (Crawley et al. 2001 and Crawley et al. 2005). Moreover, EnergyPlus makes use of a modular, loop-based method to simulate HVAC systems which helps accelerate the model construction process (Strand and Pedersen 2001). Through the object of "Setpoint Manager" in EnergyPlus, many different kinds of variables such as supply air temperature and chilled water supply temperature can be controlled and this function facilitates the construction of modern advanced supervisory control system which 
is beyond the capability of DOE-2.1 and many other simulation tools.

Although TRNSYS and DOE-2 have been widely applied in evaluating the operation performance as well as the energy consumption of buildings, some drawbacks of these tools prevent them from further application in some large complex public buildings. For example, Type 56 in TRNSYS can be used in constructing a multi-zone building but it's limited to conditions like no more than 25 zones, no more than 250 building surfaces as well as no more than 100 windows. As far as many new constructed public buildings in China are considered, their sizes far exceed the capabilities of this type. DOE-2 does not have so strict limitation on zone numbers, but its sequential simulation method can not take the interactions among load, system and plant into consideration.

\section{BUILDING DESCREPTION}

\section{General information}

It is a public building located in Shanghai Expo Park with seven floors above ground and one floor underground. The total building area of the building is 142,000sq.m. and the height is $40 \mathrm{~m}$. It will function mainly for conference; therefore it contains various types of meeting rooms and auxiliary spaces such as restaurants, press room, etc.

\section{HVAC system}

There are two types of all-air systems in this building, i.e., VAV (variable air volume) system and CAV (constant air volume) system; CAV systems mainly serve such spaces as main conference hall, multi-functional hall, banquet hall, lobby and entrance; VAV systems serve middle-size and small-size meeting rooms, office rooms and some small restaurants. The zones served by VAV systems are divided into perimeter zones and internal zones 4 meters away from the exterior walls.

The cooling and heating source plants consist of two double-mode chillers, ice storage tanks, three water-source heat pumps using Huangpu River water as the heat source/sink, and two gas boilers. The chilled water system is a constant primary flow/variable secondary flow system, while the hot water system is a variable primary flow system.

In summer, the double-mode chillers, ice storage tanks and water-source heat pumps are operated to meet the cooling loads, while the gas boilers are operated to meet the heating loads of the building. During the night, the double mode chillers are operated in ice-making mode to charge the ice storage tanks with the leaving chilled water temperature of $-5.6^{\circ} \mathrm{C}$. Whether the charging mode is completed or not depends on the leaving water temperature of ice storage tanks; i.e., once the temperature is below $-4^{\circ} \mathrm{C}$, the charging of ice storage tanks is completed and the double-mode chillers and corresponding pumps will stop running automatically. During the daytime, the ice storage tanks are discharged with warm water and double-mode chillers are operated in normal chilled water mode. The operation priority sequence is ice storage tank--water source heat pump--double mode chillers and the leaving temperature set points of them are $3.3^{\circ} \mathrm{C}, 6^{\circ} \mathrm{C}$ and $6^{\circ} \mathrm{C}$ respectively. In winter, only double-mode chillers and ice storage tanks are operated for cooling, while water-source heat pumps and gas boilers are operated for heating, with water-source heat pumps operating in priority concerning its high COP in heating mode. The space heating system is coupled with the service hot water system, with the leaving hot water temperature of $50^{\circ} \mathrm{C}$.

\section{Lighting system and others}

In the design scheme of this building, no lighting and daylighting dimming control is considered, but as there are big window to wall area ratios on all orientations of facades, daylighting dimming control is introduced into the energy efficiency model. In addition, photovoltaic (PV) system is also employed in this model to meet the electric power demand.

\section{ENERGY MODELS CONSTRUCTION}

Table 1 Heat transfer coefficient of envelope components

\begin{tabular}{|c|c|c|c|}
\hline \multirow{2}{*}{$\begin{array}{c}\text { ENVELOPE } \\
\text { COMPONENTS }\end{array}$} & \multicolumn{3}{|c|}{ U-VALUE (W/m $\left.{ }^{2} \mathbf{K}\right)$} \\
\cline { 2 - 4 } & DESIGN & EE & ASHRAE \\
\hline Exterior wall & 0.66 & 0.66 & 0.705 \\
\hline Underground wall & 0.51 & 0.51 & C-6.473* \\
\hline Roof & 0.57 & 0.57 & 0.36 \\
\hline Interior wall & 0.57 & 0.57 & 0.57 \\
\hline Window & $\begin{array}{c}1.8 / 2 / 2.3 / \\
2.4^{* *}\end{array}$ & $\begin{array}{c}1.8 / 2 / 2.3 / \\
2.4^{* *}\end{array}$ & 3.24 \\
\hline
\end{tabular}

Notes: *Time rate of steady state heat flow through unit area of the underground wall, induced by a unit temperature difference between the body surfaces and this value excludes heat resistance of soil or air film.

**Nominal U-values of four different kinds of double skin facades. 
Table 2 SHGC and Window to wall ratios (WWR) and of windows and skylights

\begin{tabular}{|c|c|c|c|c|}
\hline \multicolumn{2}{|c|}{ MODEL } & DESIGN & EE & ASHRAE \\
\hline \multirow{3}{*}{ SHGC } & Window & 0.4 & 0.279 & 0.25 \\
\cline { 2 - 5 } & Skylight & 0.4 & 0.279 & 0.19 \\
\hline \multirow{7}{*}{ WWR } & East & $69 \%$ & $69 \%$ & $40 \%$ \\
\cline { 2 - 5 } & South & $52 \%$ & $52 \%$ & $40 \%$ \\
\cline { 2 - 5 } & West & $52.5 \%$ & $52.5 \%$ & $40 \%$ \\
\cline { 2 - 5 } & North & $81 \%$ & $81 \%$ & $40 \%$ \\
\cline { 2 - 5 } & Skylight & $6 \%$ & $6 \%$ & $5 \%$ \\
\hline
\end{tabular}

Three energy simulation models are constructed: ASHRAE baseline model, Design model and Energy Efficiency (EE) model. The input data of envelopes, internal loads and HVAC systems of the three models are presented in Tables 1-5.

\section{ASHRAE baseline model}

ASHRAE baseline model is an ASHRAE 90.1-2004 compliant model based on the requirements outlined in Chapter 11 and Appendix G of the standard (ASHRAE 2004). The thermal performance of the envelopes are complied with the least requirement under climate like Shanghai which is categorized into Climate zone 3A (refer to CDD and HDD), as listed in Tables 1 and 2. No shading devices are included in this model. Furthermore, VAV systems are applied to all conditioned zones and corresponding zoning is the same as that in the design model. Perimeter conditioned zones are served by VAV boxes with terminal reheat while internal conditioned zones are served by VAV boxes without terminal reheat.

Table 3 Occupant and equipment power density (EPD)

\begin{tabular}{|c|c|c|}
\hline SPACE TYPES & $\begin{array}{c}\text { OCCUPANT DENSITY } \\
\left(\mathbf{~ m}^{\mathbf{2}} \mathbf{\text { person }}\right)\end{array}$ & $\begin{array}{c}\text { EPD } \\
\mathbf{( W / \mathbf { m } ^ { 2 }} \mathbf{)}\end{array}$ \\
\hline Lobby & 4.55 & 5 \\
\hline Atrium & 15 & 5 \\
\hline VIP Room & 2.79 & 5 \\
\hline Multi-Function Hall & 4.55 & 5 \\
\hline $\begin{array}{c}\text { 2500 seats } \\
\text { conference hall }\end{array}$ & 6.3 & 5 \\
\hline Conference hall & 6 & 5 \\
\hline Office & 1.77 & 15 \\
\hline Meeting Room & 1.56 & 5 \\
\hline Banquet Hall & 4.55 & 5 \\
\hline Restaurant & 20 & 5 \\
\hline Others & $/$ & 15 \\
\hline
\end{tabular}

Table 4 Lighting power density (LPD)

\begin{tabular}{|c|c|c|c|}
\hline SPACE TYPES & $\begin{array}{c}\text { DESIGN } \\
\text { MODEL } \\
\left(\mathbf{W} / \mathbf{m}^{2}\right)\end{array}$ & $\begin{array}{c}\text { EE } \\
\text { MODEL } \\
\left(\mathrm{W} / \mathbf{m}^{2}\right)\end{array}$ & $\begin{array}{c}\text { ASHRAE } \\
\text { MODEL } \\
\left(\mathbf{W} / \mathbf{m}^{2}\right)\end{array}$ \\
\hline Lobby & 10 & 9 & 14 \\
\hline Atrium & 10 & 9 & 14 \\
\hline VIP Room & 14 & 14 & 14 \\
\hline $\begin{array}{c}\text { Multi-Function } \\
\text { Hall }\end{array}$ & 14 & 14 & 14 \\
\hline $\begin{array}{c}2500 \text { seats } \\
\text { conference hall }\end{array}$ & 14 & 14 & 14 \\
\hline Conference hall & 14 & 14 & 14 \\
\hline Office & 12 & 12 & 12 \\
\hline Meeting Room & 11 & 14 & 14 \\
\hline Banquet Hall & 14 & 14 & 14 \\
\hline Restaurant & 15 & 14 & 14 \\
\hline Others & 5 & 5 & 5 \\
\hline
\end{tabular}

In the baseline model, cooling and heating source plants are four $2691 \mathrm{~kW}$ centrifugal chillers with nominal COP of 6.1 and two $1170 \mathrm{~kW}$ gas boilers with efficiency of $75 \%$. The loop supply water temperatures and loop supply-return temperature differences are $6.7 / 7.3^{\circ} \mathrm{C}, 29 / 5.6^{\circ} \mathrm{C}, \quad 82 / 28^{\circ} \mathrm{C}$, respectively for chilled water loop, condensed water loop and hot water loop. The efficiencies of pumps are $349 \mathrm{~kW} / 1000 \mathrm{~L} / \mathrm{s}, \quad 310 \mathrm{~kW} / 1000 \mathrm{~L} / \mathrm{s}$ and $301 \mathrm{~kW} / 1000 \mathrm{~L} / \mathrm{s}$ for chilled water, condensed water and hot water, respectively.

In addition, water supply temperature reset based on outdoor dry bulb temperature (ODDB) is applied to both chilled water loops and hot water loops. Reset schedule for chilled water loop is $7^{\circ} \mathrm{C}$ at $27^{\circ} \mathrm{C}$ and above, $12^{\circ} \mathrm{C}$ at $16^{\circ} \mathrm{C}$ and below and ramped linearly between $7^{\circ} \mathrm{C}$ and $12^{\circ} \mathrm{C}$ at ODDB between $27^{\circ} \mathrm{C}$ and $16^{\circ} \mathrm{C}$. Reset schedule for hot water loop is $82^{\circ} \mathrm{C}$ at $-7^{\circ} \mathrm{C}$ and below, $66^{\circ} \mathrm{C}$ at $10^{\circ} \mathrm{C}$ and above and ramped linearly between $82^{\circ} \mathrm{C}$ and $66^{\circ} \mathrm{C}$ at ODDB between $-7^{\circ} \mathrm{C}$ and $10^{\circ} \mathrm{C}$.

According to ASHRAE 90.1 Appendix G Table G3.1-11 Service Hot Water System, ASHARE baseline model should have the same power source as that in design model and since water-source heat pumps are the main heat source and operated in priority in design model, electric water heaters are used to provide service hot water in ASHRAE baseline model. 


\section{Design model}

The envelope parameters listed in Tables 1 and 2 are determined according to the design documentation and drawings. As the building system composition and its operation strategies have been described above, the method on how to construct the energy simulation model is discussed below and the detailed information of HVAC system and equipment is further described. Figure 1 presents the 3-D view of the design model.

\section{Air side system}

This building is of a great size plus complicated space types and distribution and many AHUs are installed to serve different spaces. However there is unnecessary and also impossible to simulate every AHU, so the whole building is divided into 89 conditioned zones and many unconditioned zones according to their orientations, space types, operating schedules and HVAC systems. One VAV (variable air volume) system, 5 CAV (constant air volume) systems with variable frequency double fans (supply fan and return fan) and 7 CAV systems with single fans are simulated to serve the 89 conditioned zones in the design model.

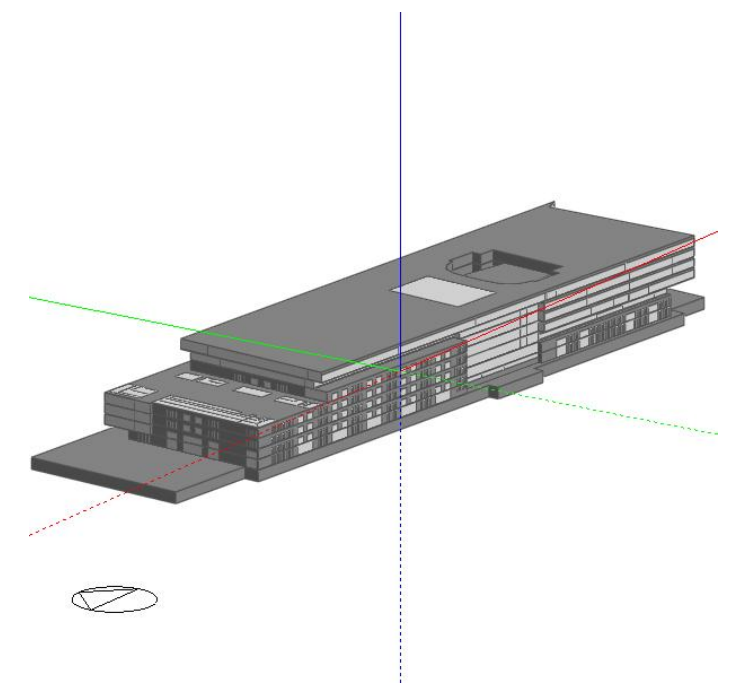

Figure 1 Energy model 3-D view of design model

\section{Chilled water system}

The cooling source plants equipped in this system are three $1758 \mathrm{~kW}$ water-source heat pumps with a nominal COP of 4.83 , two $2426 \mathrm{~kW}$ double-mode chillers with COP of 4.83 under chilled water mode and 3.09 under ice-making mode and ice storage tanks with a total capacity of 9254 RTH.

The supply water temperature and loop supply-return temperature difference is $6^{\circ} \mathrm{C}$ and $7^{\circ} \mathrm{C}$ in chilled water system loop and $29.4^{\circ} \mathrm{C}$ and $5.6^{\circ} \mathrm{C}$ in condensing water loop. The efficiency of brine pumps of ice storage system is $595 \mathrm{~kW} / 1000 \mathrm{~L} / \mathrm{s}$ and that of primary chilled water pumps is $616 \mathrm{~kW} / 1000 \mathrm{~L} / \mathrm{s}$ that of secondary chilled water pumps is $349 \mathrm{~kW} / 1000 \mathrm{~L} / \mathrm{s}$. The efficiency of all condensing water pumps is $349 \mathrm{~kW} / 1000 \mathrm{~L} / \mathrm{s}$.

In order to realize the operation strategies described above in EnergyPlus modeling, "COMPONENT SETPOINT BASED OPERATION” in Plant-Condenser Control group is used to cooperate the operation of different heating and cooling source plants, though proper setting of leaving water temperatures. Moreover, proper loop supply water temperatures are also set in the object of "Setpoint Manager". The operation sequence will be properly simulated when node temperature setpoints are specified correctly. In addition, a pond source model from EnergyPlus is used to model the Huangpu River as heat source of the water-source heat pump in the design model, because of its capability in taking into account of the effects of the changes of weather, soil temperature and solar radiation.

\section{Hot water system}

Heating source plants installed in this system are two $2800 \mathrm{~kW}$ gas boilers with efficiency of $90 \%$ and three 1780 water-source heat pumps with nominal COP of 3.79 .

For this hot water system, loop supply water temperature and loop supply-return temperature difference are $50^{\circ} \mathrm{C}$ and $10^{\circ} \mathrm{C}$. The efficiency of hot water pumps serving this system is $557 \mathrm{~kW} / 1000 \mathrm{~L} / \mathrm{s}$.

The coupling between the space heating system and the service hot water system is realized by a hot water heater without any heating capacity as a connection component in EnergyPlus model. The hot water heater draws makeup water from the municipal loop, and in order to properly evaluate the municipal makeup water temperature, the main water supply temperature is adjusted according to Shanghai TMY (typical meteorological year) weather data.

\section{Photovoltaic system}

As lacking of necessary performance information on the PV system, its nominal capacity and efficiency are used to construct a simple model. In this model, one PV panel layer is embedded into the roof construction into an integrative PV system.

\section{Energy efficiency model}

Energy efficiency model has the same configurations and operation strategies as large compared to design model, other than improving the performances of 
some components and employing additional ECMs, including:

1. Improving the shading performance of fenestration system to gain a SHGC of 0.279

2. Applying occupancy sensors in corridors and other spaces which are intermittently occupied

3. Introducing daylighting dimming control to reduce lighting electricity consumption in perimeter zones

4. Improving the COP of double-mode chillers up to 5.5 in chilled water mode and 3.92 in ice-making mode

5. Promoting the pump efficiency to the level of ASHRAE baseline model

\section{Weather data}

International Weather for Energy Calculations (IWEC) of Shanghai is used in the simulation. The IWEC data files are typical weather files suitable for use with building energy simulation programs for 227 locations outside the USA and Canada.

\section{Room air setpoints}

In this public building, the room air setpoint for such zones as entrance hall and atriums is $25^{\circ} \mathrm{C}$ for cooling and $18^{\circ} \mathrm{C}$ for heating with dead band. For other conditioned zones, room air setpoint is $25^{\circ} \mathrm{C}$ for cooling and $20^{\circ} \mathrm{C}$ for heating with dead band.

\section{Energy and source rate}

The rate of electricity and gas for commercial buildings in Shanghai are listed in Table 6 and demand charge is $30 \mathrm{RMB}$ per $\mathrm{kW}$ per month.

Table 6 Energy rates

\begin{tabular}{|c|c|c|}
\hline PERIODS & $\begin{array}{c}\text { ELECTTIC RATE } \\
\text { (RMB/kWh) }\end{array}$ & $\begin{array}{l}\text { GAS RATE } \\
\left(\mathrm{RMB} / \mathrm{Nm}^{3}\right)\end{array}$ \\
\hline $8: 00-11: 00$ & \multirow{3}{*}{1.037} & \multirow{8}{*}{2.3} \\
\hline $13: 00-15: 00$ & & \\
\hline $18: 00-21: 00$ & & \\
\hline 6:00-8:00 & \multirow{4}{*}{0.706} & \\
\hline $11: 00-13: 00$ & & \\
\hline $15: 00-18: 00$ & & \\
\hline 21:00-22:00 & & \\
\hline $22: 00-6: 00$ & 0.234 & \\
\hline
\end{tabular}

\section{ANNUAL ENERGY CONSUMPTION AND ENERGY COST ANALYSIS}

\section{Annual energy consumption and energy cost}

Table 7 lists annual energy consumption and corresponding energy cost of ASHRAE baseline model, design model and EE model. The annual gas consumption of design model is reduced by 5282 $\mathrm{Nm}^{3}$ compared to ASHRAE baseline model, while its electricity consumption is increased by 2164MWh. Meanwhile, even ice storage system installed in design model could save some energy cost by shifting part of power demand from peak time to valley time; the energy cost is still 4\% higher, because of its lower system efficiency, than ASHRAE baseline model. The annual energy cost of energy efficiency model is $12 \%$ lower than that of ASHRAE baseline model, contributed to additional ECMs employed.

Table 7 Annual energy consumption and cost

\begin{tabular}{|c|c|c|c|c|}
\hline MODEL & $\begin{array}{c}\text { ELEC- } \\
\text { (MWh) }\end{array}$ & $\begin{array}{c}\text { GAS } \\
\mathbf{( N m}^{3} \text { ) }\end{array}$ & $\begin{array}{c}\text { COST } \\
\text { (RMB) }\end{array}$ & $\begin{array}{c}\text { COST } \\
\text { SAVING }\end{array}$ \\
\hline ASHRAE & 14,478 & 55,583 & $14,860,000$ & - \\
\hline Design & 16,642 & 50,301 & $15,520,000$ & $-4 \%$ \\
\hline EE & 13,887 & 59,428 & $13,090,000$ & $12 \%$ \\
\hline
\end{tabular}

Figures 2 and 3 illustrate monthly electricity and gas consumption of the three models.

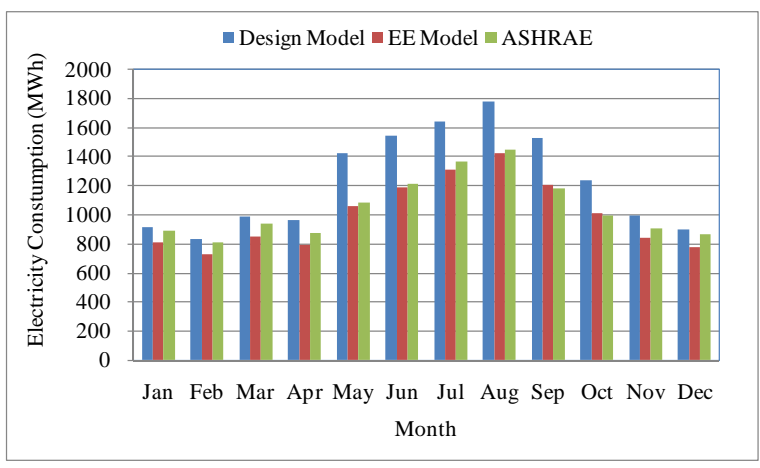

Figure 2 Monthly electricity consumption

Figure 2 shows that Energy efficiency model consumes less electricity compared to ASHRAE baseline model nearly every month except September and October. 


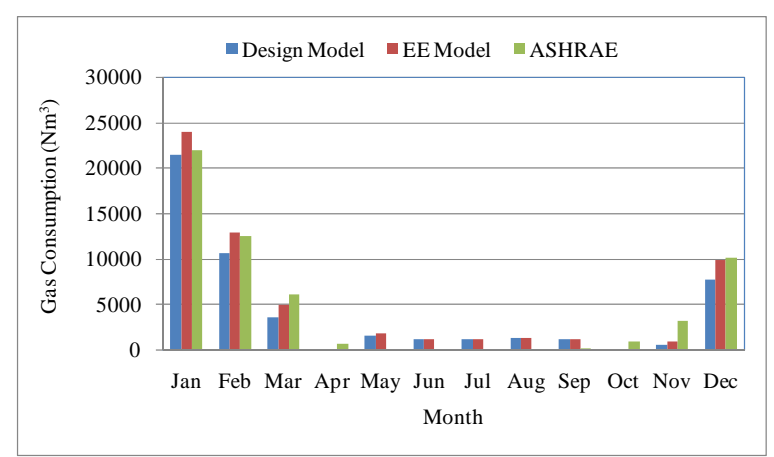

Figure 3 Monthly gas consumption

From Figure 3, in cooling season (from May to September) design model and EE model still consumes some amounts of gas while ASHRAE baseline model has no gas consumption in this period; this is mainly because gas boilers are used to provide service hot water in design model and EE model while ASHRAE baseline model employs electric water heaters for this purpose. During heating season from November to March, water-source heat pumps are operated in priority sequence in design model and EE model, therefore their monthly gas consumptions are less than those of ASHRAE baseline model. Moreover, as EE model has smaller internal heat gains due to the application of daylighting dimming and occupancy sensors, more heating is needed to meet building heating load and the gas consumptions of EE model in heating season are apparently larger than those of ASHRAE baseline model. But from the aspect of annual energy cost, ECMs added into EE model do reduce large amounts of electricity consumption as well as annual operation cost.

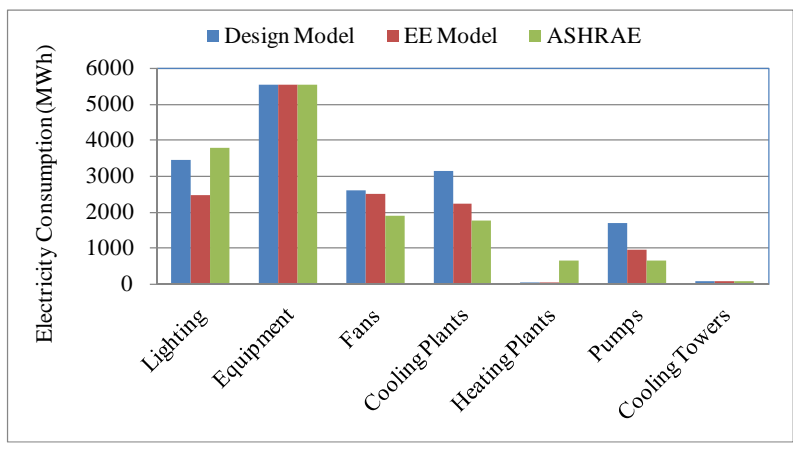

Figure 4 Annual electricity consumption breakdowns

Figure 4 outlines annual electricity consumption breakdowns for the three models. Because of different compositions of heating and cooling source plants in the three models, the electricity consumptions of cooling plants and heating plants refer to those of centrifugal chillers and electric water heaters respectively for ASHRAE baseline model while referring to those of double-mode chillers and water-source heat pumps for cooling and water-source heat pumps for heating in design model and EE model.

According to annual electricity consumption breakdown, electricity consumption of lighting system in design model is less than that of ASHRAE baseline model and with the introduction of occupancy sensors and daylighting dimming control, lighting system electricity consumption is further reduced by nearly one fourth of the baseline model. Meanwhile, less heat gain caused by less average lighting power density makes cooling load lower which certainly leads to lower energy consumption for cooling.

Through the comparison between design model and ASHRAE baseline model, HVAC system compositing of fans, pumps and heating and cooling source plants and cooling towers of design model consumes much more energy than baseline model. There are several reasons for that. In ASHRAE baseline model, centrifugal chillers with a nominal COP of 6.1 is applied while in design model watersource heat pumps with COP of 4.83 under cooling mode and double-mode chillers with COP of 4.83 under chilled water mode and 3.09 under ice making mode are used. In addition, the pump efficiency of design model is nearly half of that in ASHRAE baseline model and brine pumps of ice storage systems have to run during night when no pumps operating in ASHRAE baseline model. Higher fan energy consumptions of design model and EE model compared to ASHRAE baseline model are mainly because of continuous running of fans at a constant volume flow rate in CAV systems.

The electricity consumption of heating source plants is $38.61 \mathrm{MWh}$ for design model and $40.77 \mathrm{MWh}$ for EE model respectively but much higher for ASHRAE baseline model, arriving at 634MWh. This is because ASHRAE baseline model employs electric water heaters for service hot water purpose certainly with a lower efficiency compared to water-source heat pumps installed in design model for the purpose. In addition, water-source heat pumps are only operating under heating mode in heating season while in cooling season gas boilers will take the place for heating.

\section{Effect of PV system over annual energy consumption}

Annual energy consumption discussed above doesn't include the power generation of PV system and here the effect of PV system over annual energy consumption of design model and EE model will be 
taken into consideration. According to design documentation, $1 \mathrm{MW}$ photovoltaic system is able to generate $889,930 \mathrm{kWh}$ electric power per year. The electric power generated by the PV system is directly transmitted to the end users to meet the power demand of the building without storage devices; the extra electricity is not taken into account in the calculation. Electricity rate for power from PV system is the same as that listed in Table 6. Table 8 lists annual electricity consumptions and related costs with PV system.

Table 8 Annual electricity consumption and cost with

\begin{tabular}{|c|c|c|}
\multicolumn{3}{c|}{ PV system } \\
MODEL & $\begin{array}{c}\text { ELECTRICITY } \\
\text { CONSUMPTION } \\
(\mathbf{M W h})\end{array}$ & $\begin{array}{c}\text { ELECTRICITY } \\
\text { COST } \\
\mathbf{( R M B )}\end{array}$ \\
\hline ASHRAE & 14,478 & $14,860,000$ \\
\hline Design with PV & 15,827 & $14,540,000$ \\
\hline EE with PV & 13,116 & $12,180,000$ \\
\hline
\end{tabular}

According to results listed in Table 8, after considering the effect of $\mathrm{PV}$ system, electricity consumption of design model is more than that of ASHRAE baseline model by $9.3 \%$ while EE model saves $9.4 \%$ of the annual electricity consumption of baseline model. Moreover, power from PV system not only reduces the power consumption but also reduces large amount of electricity cost, design model and energy efficiency model save $2.1 \%$ and $18.1 \%$ of the annual electricity cost of baseline model.

\section{CONCLUSIONS}

This paper compares the advantages and disadvantages of several different kinds of energy simulation tools in simulating large public buildings and discusses how to simulate large public buildings and its building systems plus specified operation strategies within the environment of EnergyPlus. Through the simulation of a large public building in Shanghai, conclusions can be drawn as followed:

- Due to the large size and multiple functions of various spaces contained, the energy modeling of large public buildings should take account of the complicated system composition and operation strategies in order to achieve an accurate evaluation of building performance. EnergyPlus as a new generation simulation tool has the capability for this kind of simulation.

- The electricity consumption of the public buildings discussed in this paper is increased, because of its lower system efficiency, by 14.9\% compared to ASHRAE baseline model and energy cost increases by $4 \%$ even though ice storage system is installed.

- Via additional ECMs such as higher equipment efficiency and better shading performance of fenestration systems etc. EE model not only saves $4.1 \%$ electricity consumption but reduces $12 \%$ of annual electricity cost of baseline model.

- Photovoltaic system is very effective under the solar radiation condition in Shanghai and help design model and energy efficiency model saves $2.1 \%$ and $18.1 \%$ of annual electricity cost of baseline model respectively.

\section{REFERENCES}

ASHRAE Standard 90.1-2004, Energy Standard for Buildings Except Low-Rise Residential Buildings, ASHRAE Standing Standard Project Committee 90.1, 2004.

Griffith B., Pless S., Talbert B., Deru M., Torcellini P., 2003.Energy Design Analysis and Evaluation of a Proposed Air Rescue and Fire Fighting Administration Building for Teterboro Airport, National Renewable Energy Laboratory

Crawley D B, Lawrie L K, Winkelmann F C, et al, 2001. EnergyPlus: creating a new-generation building energy simulation program. Energy and Buildings, 33( 4): 319-331.

Crawley D B., Hand J W., Kummert M., Griffith B. T., 2005. Contrasting the capabilities of building energy performance simulation programs. Proceedings of IBPSA 2005 Conference, Montreal, Canada.

Ellis P. G. and Torcellini P. A., 2005. Simulating tall buildings using EnergyPlus, Proceedings of IBPSA 2005 Conference, Montreal, Canada .

Pan Y., Wu G., Hartkopf V., 2005. Whole building energy analysis tool--EnergyPlus and its application.. Journal of HV\&AC, Beijing, China.

Strand R. K., Pedersen C. O., 2001. Modularization and simulation techniques for heat balance based energy and load calculation programs: the experience of the ASHRAE Loads Toolkit and EnergyPlus, Proceedings of IBPSA 2001 Conference, Rio de Janeiro, Brazil..

U.S. DOE Energy Efficiency and Renewable Energy, Website for EnergyPlus, http://www.eere.energy.gov/buildings/energyplu $\mathrm{s} /$.

Hartkopf V., Pan Y., Wu G., Brahme R., 2003. Application of solid oxide fuel cell in building 
cooling heating and power. Journal of HV\&AC,

Beijing, China.

Table 5 HVAC system

\begin{tabular}{|c|c|c|c|}
\hline & DESIGN MODEL & EE MODEL & ASHRAE MODEL \\
\hline $\begin{array}{l}\text { Heating and cooling } \\
\text { source plants }\end{array}$ & $\begin{array}{l}\text { Water-source heat pump: } 3 \times 1758 \\
\mathrm{~kW} \text {, COP4.83 } \\
\text { Ice storage tanks: } 9254 \mathrm{RTH} \\
\text { Double-mode chillers: } 2 \times 2426 \mathrm{~kW} \text {, } \\
\text { chilled water mode COP4.83, Ice } \\
\text { making mode COP3.09 }\end{array}$ & $\begin{array}{l}\text { Water-source heat pump: } 3 \times 1758 \\
\text { kW, COP4.83 } \\
\text { Ice storage tanks: } 9254 \mathrm{RTH} \\
\text { Double-mode chillers: } 2 \times 2426 \mathrm{~kW} \text {, } \\
\text { chilled water mode COP5.5, Ice } \\
\text { making mode COP3.92 }\end{array}$ & Chillers: $4 \times 2691 \mathrm{~kW}$, COP6.1 \\
\hline $\begin{array}{l}\text { Chilled water supply } \\
\text { temperature and } \\
\text { loop DT }\end{array}$ & $6 / 7^{\circ} \mathrm{C}$ & $6 / 7^{\circ} \mathrm{C}$ & $6.7 / 7.3^{\circ} \mathrm{C}$ \\
\hline $\begin{array}{l}\text { Chilled water supply } \\
\text { temperature reset }\end{array}$ & none & none & $\begin{array}{l}\mathrm{ODDB} \leq 16^{\circ} \mathrm{C}, 12^{\circ} \mathrm{C} \\
\mathrm{ODDB} \geq 27^{\circ} \mathrm{C}, 7^{\circ} \mathrm{C} \\
16^{\circ} \mathrm{C}<\mathrm{ODDB}^{*}<27^{\circ} \mathrm{C}, \text { linear } \\
\text { change between } 7 \text { and } 12^{\circ} \mathrm{C}\end{array}$ \\
\hline Cooling tower & $\begin{array}{l}\text { Two speed cooling tower, water } \\
\text { source heat exchangers }\end{array}$ & $\begin{array}{l}\text { Two speed cooling tower, water } \\
\text { source heat exchangers }\end{array}$ & Two speed cooling tower, \\
\hline $\begin{array}{l}\text { condensed water } \\
\text { supply temperature } \\
\text { and loop DT }\end{array}$ & $29.4 / 5.6^{\circ} \mathrm{C}$ & $29.4 / 5.6^{\circ} \mathrm{C}$ & $29 / 5.6^{\circ} \mathrm{C}$ \\
\hline $\begin{array}{l}\text { Chilled water loop } \\
\text { primary pumps }\end{array}$ & $\begin{array}{l}\text { Brine pumps: } 595 \text { kW/1000L/s } \\
\text { Other Pumps: } 616 \text { kW/1000L/s }\end{array}$ & $\begin{array}{l}\text { Brine pumps: } 349 \text { kW/1000L/s } \\
\text { Other pumps: } 349 \mathrm{~kW} / 1000 \mathrm{~L} / \mathrm{s}\end{array}$ & $349 \mathrm{~kW} / 1000 \mathrm{~L} / \mathrm{s}$ \\
\hline $\begin{array}{l}\text { Chilled water loop } \\
\text { secondary pumps }\end{array}$ & $349 \mathrm{~kW} / 1000 \mathrm{~L} / \mathrm{s}$ & $349 \mathrm{~kW} / 1000 \mathrm{~L} / \mathrm{s}$ & $349 \mathrm{~kW} / 1000 \mathrm{~L} / \mathrm{s}$ \\
\hline $\begin{array}{l}\text { Condenser water } \\
\text { pumps }\end{array}$ & $310 \mathrm{~kW} / 1000 \mathrm{~L} / \mathrm{s}$ & $310 \mathrm{~kW} / 1000 \mathrm{~L} / \mathrm{s}$ & $310 \mathrm{~kW} / 1000 \mathrm{~L} / \mathrm{s}$ \\
\hline $\begin{array}{l}\text { Heating source } \\
\text { plants }\end{array}$ & $\begin{array}{l}\text { Gas boilers: } 2 \times 2800 \mathrm{~kW} \text {, } \\
\text { efficiency } 90 \% \text {; } \\
\text { Water source heat pump: } \\
3 \times 1780 \mathrm{~kW} \text {, COP3.79 }\end{array}$ & $\begin{array}{l}\text { Gas boilers: } 2 \times 2800 \mathrm{~kW} \text {, efficiency } \\
90 \% \text {; } \\
\text { Water source heat pump: } 3 \times 1780 \mathrm{~kW} \text {, } \\
\text { COP3.79 }\end{array}$ & $\begin{array}{l}\text { Gas Boilers: } 2 \times 1170 \mathrm{~kW} \text {, } \\
\text { efficiency } 75 \%\end{array}$ \\
\hline $\begin{array}{l}\text { Hot water supply } \\
\text { temperature and } \\
\text { loop DT }\end{array}$ & $50 / 10^{\circ} \mathrm{C}$ & $50 / 10^{\circ} \mathrm{C}$ & $82 / 28^{\circ} \mathrm{C}$ \\
\hline $\begin{array}{l}\text { Hot water supply } \\
\text { temperature reset }\end{array}$ & None & None & $\begin{array}{c}\mathrm{ODDB} \leq-7^{\circ} \mathrm{C}, 82^{\circ} \mathrm{C} \\
\mathrm{ODDB} \geq 10^{\circ} \mathrm{C}, 66^{\circ} \mathrm{C} \\
-7^{\circ} \mathrm{C}<\mathrm{ODDB}<10^{\circ} \mathrm{C} \text {, linear } \\
\text { change between } 66 \text { and } 88^{\circ} \mathrm{C}\end{array}$ \\
\hline Hot water pumps & $557 \mathrm{~kW} / 1000 \mathrm{~L} / \mathrm{s}$ & $301 \mathrm{~kW} / 1000 \mathrm{~L} / \mathrm{s}$ & $301 \mathrm{~kW} / 1000 \mathrm{~L} / \mathrm{s}$ \\
\hline
\end{tabular}

*ODDB: outdoor dry bulb temperature 